\title{
Primary students' reading habits of printed and e-books
}

\author{
Karen Ip \\ Teacher-Librarian \\ The Independent Schools Foundation Academy \\ Hong Kong \\ Dr. Sam Chu \\ Assistant Professor, Programme Director BSc [IM] \\ The University of Hong Kong \\ Hong Kong \\ David K.N. Sit \\ Graduate Student \\ Faculty of Business and Economics, The University of Hong Kong \\ Hong Kong
}

\begin{abstract}
Technological advancement has made books available not only in printed format but also in electronic format. To understand primary students' reading habits of printed books and e-books and discover if differences can be found in students of different gender or different level of studies, 99 primary schools students were invited to complete a questionnaire. Results show that boys generally read more than girls regardless of the book format, while boys are more positive about reading e-books and using digital libraries for reading online books. Students who read more printed books also tend to read more e-books. Implications for boys' positive attitudes towards e-books in developing their reading habits, as well as the potential development of digital libraries are drawn.
\end{abstract}

Keywords: Reading habits, printed books, e-books

\section{Introduction}

Student literacy levels have long been a concern of not only education professionals, but society in general. Research has shown that reading is beneficial to academic achievement (Cherian \& Thomas, 1995), encouraging further studies on student reading habits.

It was commonly found that gender and level of studies affect reading habits (Davies \& Bremer, 1993; Dungworth, Grimshaw, Mcknight, \& Morris, 2004; Hannesdottir, 1998). Reading habits are defined as "settled or regular tendencies to read particular types of material" (Davies \& Brember, 1993, p. 305). In terms of gender, girls are more likely to enjoy reading than boys (Dungworth et. al, 2004), which perhaps explain why they read more than boys (Hannesdottir, 1998). This is reaffirmed in a recent study by Chiu and McBrideChang (2006), where Hong Kong had the fourth smallest gap in terms of gender differences in literacy rate, although girls outscored boys in reading. Meanwhile, the content of the books boys and girls who are interested in also differs, though there is no consensus on their specific interest. In Dungworth et. al.'s study (2004), girls were more interested in magazines while boys preferred comics. Though Dungworth et.al. (2004) found both groups are equally 
interested in stories, Davies and Brember (1993) found girls have a stronger preference. All in all, gender differences are found in reading habits.

Dissimilar findings on reading habits of students of different age groups and level of studies are also discovered. It was found in terms of the number of books read or the amount of time spent on reading, some older students with lower academic achievement tend to read less. Meanwhile, some older students are found to read more (Jonathan, 1995). Ross (2002) also discovered correlations can be found in people's reading habit and their education level that educated people who possessed more reading skills are more likely to read. A study by On the other hand, Davies and Brember (1993) shows that these differences become less significant as children get older. All in all, correlations on reading habits with gender/ level of studies were found, though with different findings from different researchers.

Technological advancement has changed the format of books (De Jong \& Bus, 2004; Karim \& Hasan, 2006, Liu, 2005). Books are no longer only available in their traditional printed form, but also in electronic format such as CD-ROM, DVD or online. In particular, a dramatic shift towards e-books occurred from 1998-2001 (Albanese, 2001). These new ebooks are "an electronic version of a text that can be read on a standard desktop or laptop screen, on a PDA or other portable device, or on dedicated e-book hardware" (EDUCAUSE Learning Initiative [ELI], 2006). The flourish of e-books is both served and perpetuated by the development of complementary software and an industry focusing solely on the publication of e-books only (Chu, 2003). The availability of multimedia components such as animations and sound effects in e-books changed people's reading experience (De Jong \& Bus, 2004; Liu, 2005; Matthew, 1997). In particular, the interactive nature of e-books made them beneficial to student learning (Grant, 2004). The immediate support such as sound effects and explanation of words improved student ability in word recognition (Grant, 2004) and reading comprehension (Matthew, 1997).

Despite the large amount of literature available on student reading habits (Cherian \& Thomas, 1995; Chiu \& McBride-Chang, 2006; Davies \& Bremer, 1993; Dungworth et.al., 2004; Hannesdottir, 1998; Johnathan, 1995; Liu, 2005; Ross, 2002; Weinreich, 2000), little research in the Hong Kong context has taken student reading habits of e-books into account. As suggested by Karim and Hasan (2006) as well as Ross (2002), research in reading habits has to take note of the current advancement in technology. How the rise of e-books has changed reading patterns is controversial. For instance, according to Liu (2005), people read more when information can be obtained conveniently in a short period of time, explaining why young people today spend more time reading electronic resources. Conversely, people generally find it uncomfortable and do not prefer reading e-books on screen (Chu, 2003).

Given the benefits of e-books on student learning (Grant, 2004; Matthew, 1997) together with its increasing prevalence (Chu, 2003), student reading habits of e-books should be studied. With differences in reading habits of printed books being identified among students from different level of studies (Jonathan, 1995; Ross, 2002) and of different gender (Chiu and McBride-Chang, 2006; Davies \& Bremer, 1993; Dungworth et.al., 2004; Centre for Children's Literature, as cited in Weinreich, 2000, p.48), similar research should also be conducted on e-books. This paper thus attempts to fill in some of the gaps in the existing literature regarding student reading habits of e-books, its relationship with gender differences and level of studies as well as its correlation with the reading habits of printed books. 


\section{Method}

In an attempt to examine student reading habits of e-books, this study focused on the following five research objectives:

1. To understand primary school students ${ }^{\text {, }}$ reading habits of printed books.

2. To understand primary school students' reading habits of electronic books

3. To explore whether correlations can be found between gender and reading habits of printed and electronic books.

4. To explore whether correlations can be found between level of studies and reading habits of printed and electronic books.

5. To explore the correlation between the reading habits of printed books and ebooks

It is hoped that through identifying links between gender differences and level of studies on students' reading habits of both printed and electronic books, implications for cultivating reading habits and developing e-books can be drawn.

\section{Sample}

A convenience sample of 99 students from a Hong Kong primary school of average academic standing was recruited to complete the questionnaire. To gain a deeper understanding of the participants' response, two primary 4 students were interviewed.

\section{Materials}

The questionnaire given to the 99 students included both open and close-ended questions - requiring participants to choose among a few choices such as ratings from 1-5 (i.e. 1 not useful, 5 very useful).

According to the International Institute for Electronic Library Research, a digital/ electronic library is defined as an "organised and managed collection of mixed media materials in digital form" (as cited in Ford et.al., 1997). With e-books being defined as an electronic version of digital materials that share the characteristics of being portable, transferrable and searchable (ELI, 2006), online books obtained from the digital library are certainly one form of e-books. To simplify our study, the section focusing on students' reading habits of online books mainly questioned students on their reading habits of online books available from the Hong Kong Education City Digital Library (HKEC-DL).

According to Chan (personal communication, June 2008), the HKEC-DL was a pilot project of a commercial publisher with HKEC providing the hosting service. It was recognised to be a powerful online digital library for children that can be accessed for free in local languages (i.e. Cantonese, Putonghua and English). It provided online books targeted at primary school students with 138 in Chinese and 43 in English. Among the reserve, 42 were

\footnotetext{
${ }^{1}$ Primary school students in Hong Kong are mainly 6-12 years old with 6 levels of studies, ranging from primary 1 to 6.
} 
equipped with audio or visual effects. ${ }^{2}$ It was a good supplementary resource for students' leisure reading, which was frequently introduced to students, parents and colleagues by the school librarian where the study was conducted.

\section{Procedures}

Written questionnaires were created and distributed to three groups of students, namely primary 2,4 and 6 . They filled out the questionnaires during their library periods, which lasted for 30 minutes. Primary 4 and 6 students answered all questions on their own, while the questions were read out to primary 2 students by their teachers, and the students chose the most suitable answers. A total of 99 questionnaires were collected.

\section{Results}

To examine if gender and level of studies affect students' reading habits of both printed and e-books, further analysis was conducted by grouping the dataset of the students by gender and level of studies. In terms of gender, there were 50 male and 49 female students respectively. In terms of level of studies, students were divided into three groups according to their level of studies namely, primary 2, primary 4 and primary 6 . Correlations between the students' reading habits of printed and e-books were explored by Spearman's correlation test. It was found that students' reading habits of printed books correlated with those of e-books, while gender differences and differences in level of studies affected student reading habits of both printed and e-books.

\section{Students' reading habits of printed books}

To understand students' reading habits of printed books, their perception of total number of printed books read and average time spent on reading them was surveyed. As shown in Table 1, students perceived themselves as reading 4.1 printed books per week with 36 minutes spent on reading per day.

Table $1 \quad$ Students' reading habits of printed books as perceived by students

\section{Interview/Survey Questions}

\begin{tabular}{ll}
\hline Number of printed books read per week & 4.1 \\
Average time spent on reading printed books per day ${ }^{3}$ & $36 \mathrm{mins}$ \\
\hline Note: \\
These figures represent the students' approximated average time spent on reading as perceived by the \\
students per day in minutes.
\end{tabular}

students per day in minutes.

\footnotetext{
2 The HKEC Digital Library (http://elibrary.hkedcity.net/) was closed down since 2007 when the project was terminated by a commercial publisher. This information is no longer available in the internet.

Throughout the study, for all questions inquiring about students' average time spent on reading, respondents answered according to a scale of $1-5$, with 1 as ' 0 minute per day', 2 as 'less than 30 minutes per day', 3 as ' 30 minutes to 1 hour', 4 as ' $1-2$ hours' and 5 as 'over 2 hours per day.' Average values of each interval, which is thereby 0 minute for scale 1,15 minutes for scale 2,45 minutes for scale 3 , ninety minutes for scale 4 and 2 and a half hour for scale 5.
} 


\section{Students' reading habits of e-books}

To understand students' reading habits of e-books, they were questioned about their history of reading e-books and using the HKEC-DL. As shown in Table 2, students spent around 13.5 minutes reading e-books per day, while the average number of times they browsed the digital library was approximately 4 . Student comments on the digital library were positive, with above average rating on enjoyment and ease of use. Among the various functions of the library, as indicated in Table 3, students considered it most useful for looking for good books and identifying publishers.

Table 2 Students' reading habits of e-books

\section{Interview/Survey Questions}

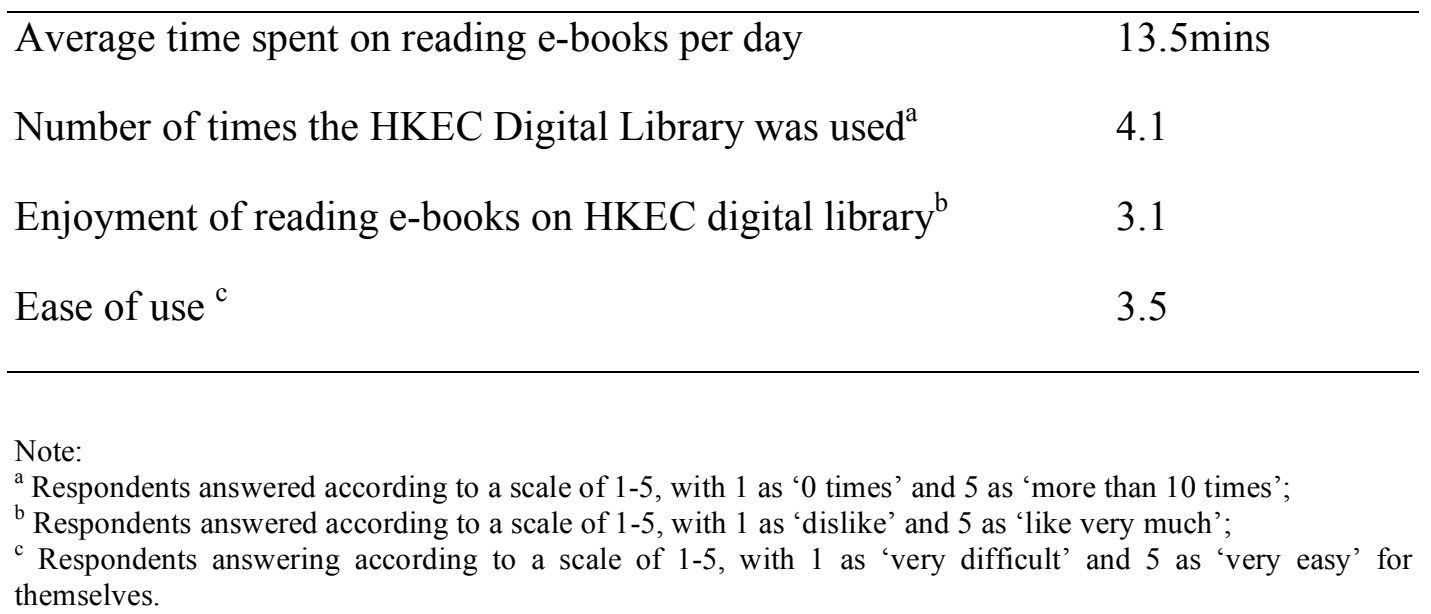
themselves. 
Table 3 Students' perception of the usefulness of the HKEC Digital Library

\section{Interview/Survey Questions}

\begin{tabular}{ll}
\hline Leisure reading** & 3.2
\end{tabular}

Looking for new books** 3

Looking for good books** 3.3

Identifying publishers for children's books** 3.3

\footnotetext{
Note:

The above table only shows the four most useful aspects of HKEC Digital Library as perceived by the students.

** Respondents answered according to a scale of $1-5$, with 1 as 'not useful' and 5 as 'very useful'.
}

\section{Links between students' reading habits of printed and e-books and their level of studies}

To further identify the underlying relations between students' reading habits of printed and electronic books and their level of studies, students' dataset were grouped according to their grade of studies. As shown in Table 4, although the total number of printed books read by upper primary students per week was smaller, the average time spent on reading per day was longer. Meanwhile, it is noteworthy that primary 4 students read the least number of printed books and spent the least time reading. This may be attributed to the differences in the level of academic achievement, as the primary 4 students involved in this study were less academically outstanding. Academically weaker students may find reading more difficult, and thus have less interest in reading.

Table $4 \quad$ Students' reading habits of printed materials (by level of studies)

\begin{tabular}{lrrr}
\hline Interview/Survey Questions & P2 & P4 & P6 \\
\hline Number of books read per week & 4.4 & 3.5 & 4.1 \\
Time spent on reading per day & 33 mins & $30 \mathrm{mins}$ & $42 \mathrm{mins}$
\end{tabular}


Similar trends were identified in the students' reading habits of e-books. As shown in Table 5, primary 2 students spent the most amount of time (18 minutes) reading e-books per day, while upper primary students spent much less time (10.5mins). However, primary 4 rated it as more enjoyable to read e-books on HKEC-DL than primary 6 students. Considering Table 5 and 6 together, of all the students, primary 6 students rated the HKECDL as least easy to use, as well as finding it least enjoyable and useful. In contrast, primary 2 students who were most positive about the digital library in terms of the ease of use, enjoyment from reading e-books in the library and usefulness, were the most frequent browsers of the digital library.

Table $5 \quad$ Students' reading habits of e-books (by level of studies)

\begin{tabular}{|c|c|c|c|}
\hline Interview/Survey Questions & $\mathbf{P 2}$ & $\mathbf{P 4}$ & $\mathbf{P 6}$ \\
\hline Average time spent on reading e-books per day & $18 \mathrm{mins}$ & $10.5 \mathrm{mins}$ & $10.5 \mathrm{mins}$ \\
\hline $\begin{array}{l}\text { Number of times the HKEC Digital Library was } \\
\text { used }^{\text {a }}\end{array}$ & 5.6 & 2.3 & 4.4 \\
\hline $\begin{array}{l}\text { Enjoyment of reading e-books on } \\
\text { HKEC digital library }^{\mathrm{b}}\end{array}$ & 3.8 & 2.9 & 2.5 \\
\hline Ease of use ${ }^{c}$ & 3.6 & 3.6 & 3.2 \\
\hline
\end{tabular}

\footnotetext{
Notes:

a Respondents answered according to a scale of $1-5$, with 1 as ' 0 times' and 5 as 'more than 10 times';

b Respondents answered according to a scale of $1-5$, with 1 as 'dislike' and 5 as 'like very much';

c Respondents answered according to a scale of $1-5$, with 1 as 'very difficult' and 5 as 'very easy' for themselves.
} 
Table 6 Students' perception of the usefulness of HKEC digital library for diverse purposes (by level of studies)

\begin{tabular}{|c|c|c|}
\hline Interview/Survey Questions*** & $\mathbf{P 2}$ & $\mathbf{P 4}$ \\
\hline$\overline{\text { Leisure reading }}$ & $*$ & $*$ \\
\hline Homework/Project research & $*$ & * \\
\hline Looking for new books & $*$ & $*$ \\
\hline Looking for good books & $*$ & $*$ \\
\hline $\begin{array}{l}\text { Learning about current events and } \\
\text { activities on reading, such as book } \\
\text { talks and exhibitions. }\end{array}$ & $*$ & \\
\hline To learn more about various authors & $*$ & \\
\hline $\begin{array}{l}\text { To identify publishers for children's } \\
\text { books }\end{array}$ & * & $*$ \\
\hline To learn Mandarin (Putonghua) & $*$ & \\
\hline To learn English & $*$ & \\
\hline $\begin{array}{l}\text { To discuss with other users in } \\
\text { discussion area }\end{array}$ & & \\
\hline Participate in reading club & * & \\
\hline
\end{tabular}

\footnotetext{
Note:

Respondents answered according to a scale of 1-5, with 1 as 'not useful' and 5 as 'very useful'.

* Students on average rated 3.0 or above out of 5 for asterisked items.
} 


\section{Links between students' reading habits of printed \& e-books and gender}

Apart from differences in reading habits among students from different grades, differences were also found in the two genders. Contrary to common understanding and research findings, our results (as demonstrated in Table 7) showed that compared to girls, boys spent more time reading printed books per day ( 6 more minutes) with more books read ( 0.9 book) per week.

Table $7 \quad$ Students' reading habits of printed books (by gender)

\begin{tabular}{lll}
\hline Interview/Survey Questions & Boys & Girls \\
\hline Number of books read per week & 4.4 & 3.5 \\
Time spent on reading per day (min) & 39 & 33 \\
\hline
\end{tabular}

A similar trend was also found in students' reading habits of e-books. As shown in Table 8, there are considerable differences between the two genders on reading habits of ebooks. Boys spent significantly more time (100\% more, i.e. 9 more minutes per day) on reading e-books and used the digital library more frequently (56\% more frequent) than girls. Furthermore, although both genders expressed an above average rating of enjoyment of reading e-books on the digital library and ease of use, boys were more positive on both items.

Table 8 Students' reading habits of e-books (by gender)

\begin{tabular}{lll}
\hline Interview/Survey Questions & Boys & Girls
\end{tabular}

\begin{tabular}{|c|c|c|}
\hline 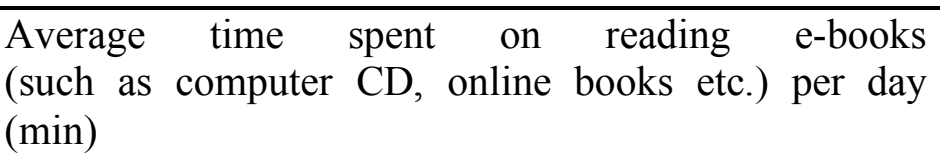 & 18 & 9 \\
\hline $\begin{array}{l}\text { Number of times visiting the Hong Kong } \\
\text { Education City digital library }{ }^{\text {, }}\end{array}$ & 5 & 3.2 \\
\hline $\begin{array}{l}\text { Enjoyment of reading e-books } \\
\text { Hong Kong Education City digital library }\end{array}$ & 3.3 & 2.8 \\
\hline Ease of use ${ }^{c}$ & 3.7 & 3.2 \\
\hline \multicolumn{3}{|c|}{$\begin{array}{l}\text { Notes: } \\
\text { a The respondents answered according to a scale of } 1-5 \text {, with } 1 \text { as ' } 0 \text { times' and } 5 \text { as 'more than } 10 \text { times' of usage } \\
\text { of the library; } \\
\text { b The respondents answered according to a scale of } 1-5 \text {, with } 1 \text { as 'dislike' and } 5 \text { as 'like very much'; } \\
\text { c The respondents answered according to a scale of } 1-5 \text {, with } 1 \text { as 'very difficult' and } 5 \text { as 'very easy'. }\end{array}$} \\
\hline
\end{tabular}


Apart from the differences in the reading habits of e-books, differences can also be found among genders on perceptions of usefulness. As shown in Table 9, boys perceived the HKEC-DL more useful than girls, rating more aspects (4 more than girls) as above average.

Table 9 Students' perception of the usefulness of HKEC digital library (by gender)

\begin{tabular}{lll}
\hline Interview/Survey Questions & Boys & Girls
\end{tabular}

Leisure reading

Homework/Project research

Looking for new books

Looking for good books

Learning about current events and activities on reading, such as book talks and exhibitions.

To learn more about various authors

To identify publishers for children's books

To learn Mandarin (Putonghua)

To learn English

To discuss with other users in discussion area

Participate in reading club

\footnotetext{
Note:

Respondents answered according to a scale of 1-5, with 1 as 'not useful' and 5 as 'very useful'.

*Students on average rated 3.0 or above out of 5 for asterisked items.
} 


\section{Correlations between students' reading habits of printed \& e-books}

To further understand the relationship between students' reading habits of printed and e-books, a correlation analysis was carried out. Data of students from all three levels of study were used for comprehensive analysis.

As shown in Table 10, students' reading habits of printed and e-books were positively correlated and statistically significant. Correlation between the number of printed books students read per week and the number of times they visited the HKEC-DL was statistically significant at 0.01 level (2-tailed). This implies that students who read more printed books read more e-books as well.

Table 10 Correlation between users' reading habits of printed and digital materials or vice versa (frequencies)

\section{\begin{tabular}{ll}
\hline Paired Questions & Correlation
\end{tabular}}

\section{Coefficient (r)}

Between number of printed books being read every week and

- time spent on reading e-books every day

- number of time visiting HKEC-DL

- like reading e-books in HKEC-DL

Between time spent on reading printed books and $0.221 *$ e-books everyday

\section{Discussion}

\section{Students of higher level of studies spent less time reading e-books and found the HKEC-DL less enjoyable}

As discussed in section 4, primary 6 students spent the most amount of time (42 minutes) per day reading printed books, even though their total number of books (4.1) read per week were smaller than others. However, they spent an equally small amount of time reading e-books (10.5 minutes per week) as primary 4 students, while rating the enjoyment of reading e-books in the digital library least enjoyable. This may be attributed to the differences in the level of difficulty of books read by students of different grades and the ability of the HKEC digital library to meet their needs. With higher level of studies, upper primary students are required to read books of more substantial content. Books targeted at lower primary students are easier and simpler than those targeted at seniors. By integrating multimedia 
functions with a textual component, e-books provide a multisensory learning experience for students. Text may be read out by the computer with words being highlighted at the same time, allowing students to train their listening skills while processing the text. These kinds of multimedia functions are usually more applicable to books with less substantial content. Upper primary students usually read books with more substantial content, and thus less multimedia components. According to research conducted by Ramirez (2003), over $80 \%$ respondents prefer to print out the digital text to facilitate reading. Hence, they may not benefit as much as lower primary students, spend less time reading e-books and find the HKEC-DL less useful. This may imply e-book companies should invest more on publishing e-books with multimedia functions targeting lower primary students, who will enjoy and benefit the most.

\section{Gender}

Contrary to results of traditional research (Hannesdottir, 1998), our study shows that boys read both more printed books and e-books than girls. It is especially noteworthy that compared to girls, boys found the e-books and HKEC-DL more appealing. This may be attributed to differences in gender attitudes towards computers and perceived computer skills. Boys are found to be more positive towards computers (Varank, 2007; Whitley, 1997), possessing more computer skills and higher self-confidence in computer literacy (Whitley, 1997). The use and access of digital libraries requires information literacy and keyboarding skills; the relevance of digital libraries for children will therefore depend on their ability to access and understand the content (Adkins, 2002). If boys are more computer literate, they will find it easier to use HKEC-DL and read e-books with greater enjoyment.

As suggested by Ross (2002), people may be encouraged to read by being allowed to choose what they read. It is 'the pleasure in the reading experience itself' (Ross, 2002, p. 95) that keeps children reading and enabling them to become confident readers. With boys being positive towards reading e-books, together with the positive correlations between the reading habits of printed books and e-books as shown in Section 4.5, young boys may be encouraged to develop their reading habits through exposing them to e-books which they are fond of.

\section{Sustainability of Digital Library}

The overall above average ratings of students on the HKEC-DL together with their high frequency of reading e-books available in the HKEC-DL demonstrated students' positive attitude towards the digital library. Meanwhile, compared to printed books, online books can save on the financial costs of printing, mailing and storage (ELI, 2006). Furthermore, digital libraries offer the economic advantages of multiple access and being available all the time (Adkins, 2002; Tanner, 2002). All these advantages, together with the positive aspects of the digital library on student learning such as increasing student commitment and understanding of subject matters through multimedia interactive activities (ELI, 2006), suggest that digital libraries are worth being further developed.

However, sustainability is a major issue in the development of digital libraries. Many digital libraries were not updated or were even closed down, even though they were proven useful, as in the case of HKEC-DL. To prevent millions of dollars invested in planning and building up digital libraries being wasted as a result of termination years after the 
development, sustainability should be one of the underlying principles of funding agencies and developers of digital libraries.

\section{Conclusion}

This study added to our knowledge of students' reading habits of e-books and its correlation with their reading habits of printed books. It is shown that links can be found between the reading habits of students on printed/e-books and their gender/ level of studies. The more senior the students are, the lesser the numbers of printed books are read but with more time spent on reading per week. Meanwhile, senior students are less positive on e-books and spend less time on reading e-books. Contrary to previous research, in our study, boys read both more printed books and e-books than girls. Meanwhile, they are more positive on the use of HKEC-DL and reading e-books. Finally, correlations are found between reading habits of printed books and e-books regardless of gender and level of studies. The more printed books one reads, the more e-books one reads.

Based on our study, a few suggestions were made including focusing on the development of e-books for junior students who enjoy and may benefit the most from the ebook. Secondly, boys can be encouraged to develop reading habits through exposure to ebooks, which they may be more interested in. Finally, sustainability of the digital library which is valued by the students should be ensured.

\section{Limitation and Further Studies}

Focus was placed on online books in the session studying students' reading habits of e-books. With online books being one format of e-books and sharing the characteristics of ebooks (ELI, 2006), future study may broaden the scope by researching on other forms of ebooks. This may provide a complete picture of students' reading habits of e-books and clarify if the present results can be generalized to electronic books that vary from the formats focused in this study.

One group of students studied in this research was of lower academic performance. Future study may control the differences in students' academic qualifications to eliminate the effects of academic achievements on reading habits.

\section{Acknowledgement}

We would like to thank Ms. Josephine Yuen and Ms. Karen Chui for their contributions to this study.

\section{References}

Adkins, D. (2002). The digital library and younger users. In G. E. Gorman (Ed.), The digital factor in library and information services. International yearbook of library and information management 2002/2003 (pp. 133-155). London : Library Association Pub.

Albanese, A. R. (2001). Moving from books to bytes. Library Journal, 126(14), 52-54. Retrieved May 28, 2008, from ABI/INFORM Global database. (Document ID: 80399398).

Cherian, V. I., \& Thomas, V. (1995) Reading habits and academic achievement of Basotho children. Perceptual and Motor Skills, 80, 497-498. 
Chiu, M. M., \& McBride-Chang, C. (2006). Gender, context, and reading: a comparison of students in 41 countries. Scientific Studies of Reading, 10, 331-362.

Chu, H. (2003). Electronic books: viewpoints from users and potential users. Library Hi Tech, 21(3), 340-346.

Davies, J., \& Brember, I. (1993). Comics or Stories? Differences in the Reading Attitudes and Habits of Girls and Boys in years 2, 4 and 6. Gender and Education, 5(3), 305-320.

De Jong, M. T., \& Bus, A. G. (2004). The efficacy of electronic books in fostering kindergarten children's emergent story understanding. Reading Research Quarterly, 39(4), 278-393.

Dungworth, N., Grimshaw, S., Mcknight, C., \& Morris, A. (2004). Reading for pleasure?: a summary of the findings from a survey of the reading habits of year 5 pupils. New Review of Children's Literature and Librarianship, 10(2), 169-188.

EDUCAUSE Learning Initiative (2006). 7 things you should know about......E-Books. Retrieved 20 May, 2008 from www.educause.edu/eli

Ford, N., Booth, A., Miller, D., Turnock, E., Ralph, J., \& O’Rourke, A. (1997). Towards the evidence-based electronic library. In C. Davies, \& A. Ramsden (Ed.), Electronic Library Visual Information Research Papers from the fourth ELVIRA conference 6-8 May 1997 (pp.229-236). London, Aslib The Association for Information Management.

Grant, J. M. A. (2004). Are electronic books effective in teaching young children reading and comprehension? International Journal of Instructional Media, 31(3), 303-308.

Hannesdottir, S.K. (1998). From books to the information superhighway; young people's reading habits and Internet use in Iceland. International Association of School Librarianship. 55-68.

Jonathan, W. (1995). Patterns of reading among teenage boys: the reading habits and book preferences of 13-15year-old boys. New Library world, 96 (1112), 10-16.

Karim, N. S. A., \& Hasan, A. (2007). Reading habits and attitude in the digital age: Analysis of gender and academic program differences in Malaysia. Reading habits and attitude, 25(3), 285-298.

Liu, Z. (2005). Reading behaviour in the digital environment: Changes in reading behaviour over the past ten years. Journal of Documentation, 61(6), 700-712.

Matthew, K. (1997). A comparison of influence of interactive CD-ROM storybooks and traditional print storybooks on reading comprehension. Journal of Research on Computing in Education, 29(3), 263275.

Ramirez, E. (2003). The impact of the internet on the reading practices of a university community: the case of UNAM. Proceedings of the $69^{\text {th }}$ IFLA General Conference and Council. Retrieved May 29, 2008 from www.ifla.org/IV/ifla69/papers/019e-Ramirez.pdf

Ross, C.S. (2002). Reading in a digital age. In G. E. Gorman (Ed.), The digital factor in library and information services. International yearbook of library and information management 2002/2003 (pp. 91-111). London : Library Association Pub.

Tanner, S.(2002). The economic opportunities and costs of developing digital libraries and resources. In G.E. Gorman (Ed.), The Digital Factor in Library and Information Services (pp.68-88). London: Facet Publishing.

Varank, I. (2007). Effectiveness of Quantitative Skills, Qualitative Skills, and Gender in Determining Computer Skills and Attitudes: A Causal Analysis. The Clearing House, 81(2), 71-80. Retrieved May 29, 2008, from Academic Research Library database. (Document ID: 1404869851).

Weinreich, T. (2000). Children's reading habits and their use of the media: How much do they read? What do they prefer to read? How do they read? International Association of School Librarianship. Selected Papers from the ... Annual Conference,33. Retrieved May 28, 2008, from ProQuest Education Journals database. (Document ID: 103534248).

Whitely, B. (1997). Gender differences in computer related attitudes and behavior: A meta-analysis. Computers in Human Behavior, 13 (1), 1-22.

\section{Statement of Originality}

This statement certifies that the paper above is based upon original research undertaken by the author and that the paper was conceived and written by the author(s) alone and has not been published elsewhere. All information and ideas from others is referenced. 